\title{
CHECKLIST OF SPIDERS (ARACHNIDA: ARANEAE) OF MADHYA PRADESH AND CHHATTISGARH
}

\author{
Pawan Gajbe \\ Central Regional Station, Zoological Survey of India, 424, New Adarsh Colony, Kamla Nehru Nagar, Jabalpur, \\ Madhya Pradesh 482002, India
}

\begin{abstract}
A checklist of 186 species of spiders in 69 genera under 24 families distributed in Madhya Pradesh and Chhattisgarh has been given along with a complete bibliography.
\end{abstract}

\section{Keywords}

Araneae, checklist, Chhattisgarh, Madhya Pradesh, spider

\section{Introduction}

Spiders are one of the most familiar and fascinating creatures. They are ubiquitous and diverse predators in terrestrial ecosystems and are found in diverse habitats. The erstwhile Central Indian State of Madhya Pradesh is now divided into two states, Madhya Pradesh and Chhattisgarh. Many species of spiders are known from these states but there is not a complete record of all species reported from this region. The checklist provided in Table 1 attempts to give a precise account of spiders known from Madhya Pradesh and Chhattisgarh. This list is based on published records and identified specimens in the National Zoological Collection, Zoological Survey of India.

A review of the literature available on Indian spiders reveals that the earliest contributions were by Stoliczka (1869), Karsch (1873), Simon (1887), Thorell (1895), Pocock (1900), and in the twentieth century by Sherriffs (1919), Gravely (1921), Narayan (1925), Reimoser (1934) and Dyal (1935). The spiders of many families were practically unknown from Madhya Pradesh before Tikader $(1980,1982)$ and Tikader and Malhotra (1980) who described some species of the families Thomisidae, Philodromidae, Lycosidae, Araneidae and Gnaphosidae from Madhya Pradesh in 'Fauna of India, Araneae' volumes 1 and 2. Tikader and Gajbe (1976) described a few species of family Gnaphosidae from Madhya Pradesh. The spiders of Madhya Pradesh were studied in detail by Gajbe (1987-1999), who described many new species from this region. Gajbe (1992a) described the family Mimetidae, and Platnick (1991) and Platnick and Gajbe (1994) recorded species of the family Cithaeronidae for the first time from Madhya Pradesh. Gajbe (1995a) recorded 13 species from Indravati Tiger Reserve, Chhattisgarh. Rane and Singh (1977) recorded five species and Gajbe (1995b) 14 species from Kanha Tiger Reserve, Madhya Pradesh. In recent times, Gajbe and Gajbe $(1999,2000)$ have described 32 new species, Bhandari and Gajbe (2001) 10 new species, and Gajbe (2003) one new species of spider from Jabalpur District, Madhya Pradesh. Gajbe (1999) also recorded many lynx spiders of the genera Oxyopes and Peucetia (Family Oxyopidae) from Madhya Pradesh and Chhattisgarh. Gajbe (2001, 2003a,b) has recorded 102 species from Jabalpur District in Madhya Pradesh and further identified 25 new species from Madhya Pradesh, provisionally placed under the genera Scytodes, Triaeris, Pholcus, Thomisus, Philodromus, Misumenoides, Runcinia, Tegenaria, Heteropoda, Phidippus, Rhene, Eucta, Tetragnatha, and Dolomedes, which will be described in detail, separately. On the basis of these species and some other species identified from Seoni District in Madhya Pradesh, the families Oonopidae, Tetragnathidae, Heteropodidae, Pisauridae, Pholcidae and Dictynidae are also being reported from Madhya Pradesh.

In the checklist (Table 1), the species known only from Madhya Pradesh are unmarked; species known from both Madhya Pradesh and Chhattisgarh are marked with a single asterisk (*), while species known only from Chhattisgarh are marked with two asterisks $(* *)$. Of the reported 186 species in 69 genera under 24 families, a total of 170 species in 67 genera under 23 families are known from Madhya Pradesh, while 49 species in 27 genera under 10 families are known from Chhattisgarh. Totally, 34 species are distributed in both the states.

\section{Acknowledgements}

Thanks are due to Dr. J.R.B. Alfred, Director, Z.S.I., Kolkata, and Dr. K. Chandra, Joint Director, Z.S.I., C.R.S., Jabalpur, for providing facilities. 


\section{References}

Bhandari, R. and P. Gajbe (2001a). A study of three new species of spiders of the genera Chorizopes Cambridge, Larinia Simon and Neoscona Simon (Araneae: Araneidae) from Madhya Pradesh, India. Records of the Zoological Survey of India 99(1-4): 59-63.

Bhandari, R. and P. Gajbe (2001b). Description of three new species of spiders of the genera Thomisus Walckenaer, Oxyptila Simon and Xysticus Koch (Araneae: Thomisidae) from Madhya Pradesh, India. Records of the Zoological Survey of India 99(1-4): 81-85.

Bhandari, R. and P. Gajbe (2001c). Description of four new species of spiders of the families Uloboridae, Philodromidae, Gnaphosidae and Lycosidae (Arachnida: Araneae) from Madhya Pradesh, India. Records of the Zoological Survey of India 99(1-4): 87-93.

Bhandari, R. and P. Gajbe (2001d). An ecological study of some spiders from Jabalpur, pp.121-127. In: Singh, S.M. (Ed.), Contemporary Trends in Biological Sciences. Prof. S.C. Pathak Festschrift, R.D. University, Jabalpur, India.

Biswas, B. and K. Biswas (1992). Araneae: Spiders, pp.357-500. In: State Fauna Series-3: Fauna of West Bengal, Part 3. Zoological Survey of India Publication.

Dyal, S. (1935). Spiders of Lahore. Bulletin of the Department of Zoology, Panjab University 1: 117-252.

Gajbe, P. (2001). A faunistic survey of spiders (Arachnida) and their diversity in and around Jabalpur with special reference to their ecology. Ph.D. Thesis. Rani Durgavati University, Jabalpur, M.P., India.

Gajbe, P. (2003a). Description of a new species of spider of the genus Castianeira Keyserling (Araneae: Clubionidae) from Madhya Pradesh. Zoos' Print Journal 18(3): 1034-1036.

Gajbe, P. (2003b). A checklist of spiders (Arachnida: Araneae) of Jabalpur, Madhya Pradesh, India. Records of the Zoological Survey of India 101(3-4): 43-47.

Gajbe, U.A. (1987). A new Scopodes spider from India (Araneae: Gnaphosidae). Bulletin of the Zoological Survey of India 8: 285-287.

Gajbe, U.A. (1988). On a collection of spiders of the family Gnaphosidae from India (Araneae: Arachnida). Records of the Zoological Survey of India 85(1): 59-74.

Gajbe, U.A. (1992a). New record of spider Hersilia savignyi Lucas (Family: Hersiliidae) from Madhya Pradesh, India with a description of male. Records of the Zoological Survey of India 90(1-4): 117-119.

Gajbe, U.A. (1992b). A new Liodrassus spider from India (Araneae: Gnaphosidae). Records zoological Survey of India 91(2): 247-250.

Gajbe, U.A. (1992c). On two new species of Haplodrassus spiders from India (Araneae: Gnaphosidae). Records of the Zoological Survey of India 91(2): 247-250.

Gajbe, U.A. (1992d). On two new species of Haplodrassus spiders from India (Araneae: Gnaphosidae). Records of the Zoological Survey of India 91(3-4): 313-317.

Gajbe, U.A. and P.D. Rane (1992). A new Monaeses spider from Madhya Pradesh, India (Araneae: Thomisidae). Records of the Zoological Survey of India 91(3-4): 395-397.

Gajbe, U.A. (1992e). A new Mimetus spider from India (Araneae: Mimetidae). Records of the Zoological Survey of India 91(3-4): 427429.

Gajbe, U.A. (1995a). Spiders, pp. 53-56. In: Fauna of Conservation Areas 6: Fauna of Indravati Tiger Reserve, Madhya Pradesh.Zoological Survey of India Publication.

Gajbe, U.A. (1995b). Spiders, pp. 27-30. In: Fauna of Conservation Areas 7: Fauna of Kanha, Tiger Reserve Madhya Pradesh. Zoological Survey of India Publication.
Gajbe, U.A. (1999). Studies on some spiders of the family Oxyopidae (Araneae: Arachnida) from India. Records of the Zoological Survey of India 97(3): 31-79.

Gajbe, U.A. and P. Gajbe (1999a). Two new species of Peucetia Thorell (Araneae: Oxyopidae) from Jabalpur, Madhya Pradesh. Geobios 18(1): 9-12.

Gajbe, U.A. and P. Gajbe (1999b). Two new species of Oxyopes Latreille (Araneae: Oxyopidae) from Jabalpur, Madhya Pradesh. Geobios 18(1): 13-16.

Gajbe, U.A. and Gajbe, P. (1999c). A new species of spider of the genus Tmarus Simon (Araneae: Thomisidae) from Madhya Pradesh, India. Records of the Zoological Survey of India 97(3): 141-143.

Gajbe, U.A. and P. Gajbe (1999d). On two new species of spiders of the genus Xysticus Koch (Araneae: Thomisidae) from Madhya Pradesh, India. Records of the Zoological Survey of India 97(3): 145-148.

Gajbe, U.A. and P. Gajbe (1999e). A new species of spider of the genus Tibellus Simon from Madhya Pradesh (Araneae: Philodromidae). Records of the Zoological Survey of India 97(3): 191-193.

Gajbe, U.A. and P. Gajbe (1999f). A new species of spider of the genus Philodromus Walckenaer (Araneae: Philodromidae) from Madhya Pradesh, India. Records of the Zoological Survey of India 97(3): 195197.

Gajbe, U.A. and P. Gajbe (1999g). A new species of spider of the genus Thanatus Koch (Araneae: Philodromidae) from Madhya Pradesh, India. Records of the Zoological Survey of India 97(3): 199-201.

Gajbe, U.A. and P. Gajbe (1999h). On three new species of spiders of the genus Hippasa Simon (Araneae: Lycosidae) from Jabalpur, Madhya Pradesh, India. Records of the Zoological Survey of India 97(4): 23-28. Gajbe, U.A. and P. Gajbe (1999i). A new Cyrtophora spider (Araneae: Araneidae) from Jabalpur, Madhya Pradesh, India. Records of the Zoological Survey of India 97(4): 29-31.

Gajbe, U.A. and P. Gajbe (1999j). A new species of the genus Philodromus Walckenaer (Araneae: Philodromidae) from Madhya Pradesh, India. Records of the Zoological Survey of India 97(4): 91-93. Gajbe, U.A. and P. Gajbe (1999k). A new species of the genus Pardosa Koch (Araneae: Lycosidae) from Madhya Pradesh, India. Records of the Zoological Survey of India 97(4): 95-97.

Gajbe, U.A. and P. Gajbe (1999). A new species of the genus Sergiolus Simon from Madhya Pradesh, India (Araneae: Gnaphosidae). Records of the Zoological Survey of India 97(4): 99-101.

Gajbe, U.A. and P. Gajbe (2000a). A new species of the genus Philodromus Walckenaer (Araneae: Philodromidae) from Madhya Pradesh, India. Records of the Zoological Survey of India 98(2): 51-53. Gajbe, U.A. and P. Gajbe (2000b). A new species of spider of the genus Thomisus Walckenaer (Araneae: Thomisidae) from Madhya Pradesh, India. Records of the Zoological Survey of India 98(2): 55-57. Gajbe, U.A. and P. Gajbe (2000c). A new species of spider of the genus Neoscona Simon (Araneae: Araneidae) from Madhya Pradesh, India. Records of the Zoological Survey of India 98(2): 119-121.

Gajbe, U.A. and P. Gajbe (2000d). A new species of spider of the genus Oxyopes Latreille (Araneae: Oxyopidae) from Madhya Pradesh, India. Records of the Zoological Survey of India 98(2): 123-125.

Gajbe, U.A. and P. Gajbe (2000e). A new species of the genus Runcinia Simon (Araneae: Thomisidae) from Madhya Pradesh, India. Records of the Zoological Survey of India 98(2): 155-157.

Gravely, F.H. (1921). The spiders and scorpions of Barkuda Island. Records of the Indian Museum 22: 399-421.

Karsch, E. (1873). Verzeichniss westfälischer Spinnen (Araneiden). Verh. naturh. Ver. preuss. Rhein. Westfäl. 10: 113-160. 


\section{Table 1. Checklist of spiders of Madhya Pradesh and Chhattisgarh}

\section{Scientific name}

\section{Order Araneae}

Suborder Labidognatha

Filistatidae

Filistata nicobarensis (Tikader, 1977) **

Filistata poonaensis (Tikader, 1963)*

\section{Scytodidae}

Scytodes kinsukus Patel, 1975

Scytodes propinqua Stoliczka, 1869

Scytodes thoracica (Latreille, 1802)

Pholcidae

Artema atlenta Walckenaer, 1837

Pholcus sp.

Oonopidae

Triaeris sp.

Mimetidae

Mimetus tikaderi Gajbe, 1992**

Eresidae

Stegodyphus pacificus Pocock, 1900

Stegodyphus sarasinorum Karsch, 1891*

Stegodyphus socialis Pocock, 1900

$\underline{\text { Oecobiidae }}$

Oecobius putus O. P. Cambridge, 1876

Urocteidae

Uroctea indica Pocock, 1900

Hersiliidae

Hersilia savignyi Lucas, 1836*

$\underline{\text { Uloboridae }}$

Uloborus danolius Tikader, 1969

Uloborus jabalpurensis Bhandari \& Gajbe, 2001

Uloborus khasiensis Tikader, 1969

\section{Tetragnathidae}

Eucta sp.

Tetragnatha sp.

Araneidae

Araneus mitifica (Simon, 1886)*

Araneus nympha (Simon, 1889)

Argiope aemula (Walckenaer, 1842)*

Argiope anasuja Thorell, $1887^{* *}$

Argiope pradhani Sinha, 1952**

Argiope pulchella Thorell, 1881*

Chorizopes tikaderi Bhandari \& Gajbe, 2001

Cyclosa bifida (Doleschall, 1859)

Cyclosa confraga (Thorell, 1892)

Cyclosa hexatuberculata Tikader, 1982*

Cyclosa insulana (Costa, 1834)

Cyclosa moonduensis Tikader, 1963

Cyclosa spirifera Simon, 1889*

Cyrtophora bidenta Tikader, 1970

Cyrtophora cicatrosa (Stoliczka, 1869)

Scientific name

Cyrtophora citricola (Forskål, 1775)

Cyrtophora jabalpurensis Gajbe \& Gajbe, 1999

Herennia ornatissima (Doleschall, 1859)**

Larinia bharatae Bhandari \& Gajbe, 2001

Larinia chloris (Audouin, 1826)

Leucauge celebesiana (Walckenaer, 1842)

Leucauge decorata (Blackwall, 1864)

Neoscona bengalensis Tikader \& Bal, 1981

Neoscona biswasi Bhandari \& Gajbe, 2001

Neoscona elliptica Tikader \& Bal, 1981

Neoscona laglaizei (Simon, 1877)

Neoscona molemensis Tikader \& Bal, 1981**

Neoscona mukerjei Tikader, 1980*

Neoscona nautica (L. Koch, 1875)

Neoscona odites (Simon, 1906)

Neoscona pavida (Simon, 1906)

Neoscona platnicki Gajbe \& Gajbe, 2000

Neoscona poonaensis Tikader \& Bal, 1981

Neoscona rumpfi (Thorell, 1878)

Neoscona sinhagadensis (Tikader, 1975)*

Neoscona theis (Walckenaer, 1842)*

Nephila kuhlii Doleschall, 1859

Nephila maculata (Fabricius, 1793)

Zygeilla indica Tikader \& Bal, 1980

Zygeilla melanocrania (Thorell, 1887)

Lycosidae

Arctosa himalayensis Tikader \& Malhotra, 1980

Arctosa indicus Tikader \& Malhotra, 1980

Hippasa agelenoides (Simon, 1884)*

Hippasa fabreae Gajbe \& Gajbe, 1999

Hippasa greenalliae (Blackwall, 1867)*

Hippasa hansae Gajbe \& Gajbe, 1999

Hippasa olivacea (Thorell, 1887)

Hippasa partita (O. P. Cambridge, 1876)*

Hippasa pisaurina Pocock, 1900

Hippasa wigglesworthi Gajbe \& Gajbe, 1999

Lycosa bistriata (Gravely, 1924)

Lycosa nigrotibialis (Simon, 1884)

Lycosa poonaensis Tikader \& Malhotra, 1980**

Lycosa shaktae Bhandari \& Gajbe, 2001

Pardosa amkhasensis Tikader \& Malhotra, 1976

Pardosa annandalei (Gravely, 1924)

Pardosa birmanica Simon, 1884*

Pardosa jabalpurensis Gajbe \& Gajbe, 1999

Pardosa mukundi Tikader \& Malhotra, 1980

Pardosa sumatrana (Thorell, 1890)*

Pisauridae

Dolomedes sp.

Oxyopidae

Oxyopes ashae Gajbe, 1999**

Oxyopes bharatae Gajbe, 1999

Oxyopes jabalpurensis Gajbe \& Gajbe, 1999

Oxyopes kamalae Gajbe, 1999

\section{Scientific name}

Oxyopes ketani Gajbe \& Gajbe, 1999

Oxyopes kusumae Gajbe, 1999

Oxyopes naliniae Gajbe, 1999*

Oxyopes pankaji Gajbe \& Gajbe, 2000

Oxyopes rukminiae Gajbe, 1999**

Peucetia ashae Gajbe \& Gajbe, 1999

Peucetia choprai Tikader, 1965

Peucetia jabalpurensis Gajbe \& Gajbe, 1999

Peucetia pawani Gajbe, 1999**

Peucetia rajani Gajbe, 1999*

Peucetia viveki Gajbe, 1999

Peucetia yogeshi Gajbe, 1999**

Agelenidae

Tegenaria sp.

Dictynidae

Dictyna shiprai Tikader, 1966

$\underline{\text { Clubionidae }}$

Castianeira adhartali Gajbe, 2003

Cheiracanthium trivialis (Thorell, 1895)

\section{Cithaeronidae}

Cithaeron indicus Platnick \& Gajbe, 1994*

Inthaeron rossi Platnick, 1991

\section{Gnaphosidae}

Callilepis chakanensis Tikader, 1982

Callilepis lambai Tikader \& Gajbe, 1977*

Callilepis rukminiae Tikader \& Gajbe, 1977

Drassodes himalayensis Tikader \& Gajbe, 1975*

Drassodes meghalayaensis Tikader \& Gajbe, 1977

Drassodes oppenheimeri Tikader, 1973*

Drassodes pashanensis Tikader \& Gajbe, 1977*

Drassodes sagarensis Tikader, 1982

Drassyllus khajuriai Tikader \& Gajbe, 1976

Drassyllus mahabalei Tikader, 1982

Geodrassus sirmourensis (Tikader \& Gajbe, 1977)

Gnaphosa jodhpurensis Tikader \& Gajbe, 1977

Gnaphosa pauriensis Tikader \& Gajbe, 1977*

Gnaphosa poonaensis Tikader, 1973

Haplodrassus sataraensis Tikader \& Gajbe, 1977*

Herpyllus goaensis Tikader, $1982^{*}$

Liodrassus tikaderi Gajbe, 1993

Megamyrmecion ashae Tikader \& Gajbe, 1977

Poecilochroa barmani Tikader, 1982

Scopodes maitraiae Tikader \& Gajbe, 1977*

Scopodes tikaderi Gajbe, $1987^{\star *}$

Scotophaeus poonaensis Tikader, 1982

Sergiolus lamhetaghatensis Gajbe \& Gajbe, 1999

Sergiolus poonaensis Tikader \& Gajbe, 1976*

Sergiolus singhi Tikader \& Gajbe, 1976

Sosticus dherikanalensis Gajbe, 1979

Sosticus jabalpurensis Bhandari \& Gajbe, 2001

Sosticus poonaensis Tikader, 1982

Zelotes ashae Tikader \& Gajbe, 1976 


\section{Scientific name}

Zelotes jabalpurensis Tikader \& Gajbe, 1976

Zelotes mandae Tikader \& Gajbe, 1977

Zelotes mandlaensis Tikader \& Gajbe, 1976

Zelotes nasikensis Tikader \& Gajbe, 1976

Zelotes sataraensis Tikader \& Gajbe, 1979*

Zelotes shantae Tikader, 1982

\section{Heteropodidae}

Heteropoda sp.

\section{Philodromidae}

Dieta elongata Tikader, 1980

Philodromus ashae Gajbe \& Gajbe, 1999

Philodromus barmani Tikader, 1980

Philodromus betrabatai Tikader, 1966

Philodromus bhagirathai Tikader, 1966

Philodromus domesticus Tikader, 1962

Philodromus durvei Tikader, 1980

Philodromus jabalpurensis Gajbe \& Gajbe, 1999

Philodromus pali Gajbe \& Gajbe, 2000

Thanatus jabalpurensis Gajbe \& Gajbe, 1999

Thanatus ketani Bhandari \& Gajbe, 2001

Tibellus elongatus Tikader, 1960

Tibellus jabalpurensis Gajbe \& Gajbe, 1999

Tibellus poonaensis Tikader, 1962

\section{Thomisidae}

Amyciaea forticeps (O. P. Cambridge, 1873)**

Misumenoides sp.

Monaeses jabalpurensis Gajbe \& Rane, 1992

Oxyptila amkhasensis Tikader, 1980

Oxyptila jabalpurensis Bhandari \& Gajbe, 2001

\section{Scientific name}

Runcinia escheri Reimoser, 1934

Runcinia yogeshi Gajbe \& Gajbe, 2000

Synaema brunettii Tikader, 1962

Synaema decorata Tikader, 1960*

Synaema mysorensis Tikader, 1980

Thomisus cherapunjeus Tikader, 1966*

Thomisus elongatus Stoliczka, 1869**

Thomisus lobosus Tikader, 1965**

Thomisus katrajghatus Tikader, 1963

Thomisus projectus Tikader, 1960*

Thomisus pugilis Stoliczka, 1869

Thomisus rajani Bhandari \& Gajbe, 2001

Thomisus sundari Gajbe \& Gajbe, 2000

Tmarus jabalpurensis Gajbe \& Gajbe, 1999

Tmarus pachpediensis Tikader, 1980

Xysticus bengalensis Tikader \& Biswas, 1974

Xysticus bharatae Gajbe \& Gajbe, 1999

Xysticus jabalpurensis Gajbe \& Gajbe, 1999

Xysticus joyantius Tikader, 1966*

Xysticus kali Tikader \& Biswas, 1974

Xysticus minutus Tikader, 1960*

Xysticus shyamrupus Tikader, 1966

Xysticus tikaderi Bhandari \& Gajbe, 2001

Salticidae

Marpissa dhakuriensis Tikader, 1974

Marpissa mandali Tikader, 1974

Phidippus sp.

Rhene sp.

Zygoballus narmadaensis Tikader
Narayan, K. (1915). Notes on ant-like spiders of the family Attidae in the collection of the Indian Museum. Records of the Indian Museum 11: 393-406.

Platnick, N.I. (1991). A revision of the ground spider family Cithaeronidae (Araneae, Gnaphosoidea). American Museum Novitates 3018: 1-13.

Platnick, N.I. and U.A. Gajbe (1994). Supplementary notes on the ground spider family Cithaeronidae (Araneae, Gnaphosoidea). Journal of Arachnology 22: 82-83.

Pocock, R.I. (1900). The Fauna of British India, Arachnida. Taylor \& Francis, London, 279pp.

Pocock, R.I. (1904). Arachnida. In: Fauna and Geography of the Maldive and Laccadive Archipelagoes. London, 2(3): 797-805.

Rane, P.D. and R.K. Singh (1977). Spiders (Arachnida: Araneida) from Kanha National Park, Madhya Pradesh, India. Newsletter
Zoological Survey of India 3(2): 84.

Reimoser, E. (1934). Araneae aus Sud-Indien. Revue Swisse Zool. 41: 465-511.

Sherriffs, W.R. (1919). A contribution to the study of south Indian arachnology. Annals and Magazine of Natural History 4(9): 220-253.

Simon, E. (1887). Etude sur les arachnides de l'Asie méridionale faisant partie des collections de l'Indiam Museum (Calcutta). I. Arachnides reculeeis à Tavoy (Tenasserim) par Moti Ram. Journal of the Asiatic Society of Bengal 56: 101-117.

Stoliczka, F. (1869). Contribution towards the knowledge of Indian Arachnoidea. Journal of the Asiatic Society of Bengal 38(2): 201251.

Thorell, T. (1895). Descriptive catalogue of the Spiders of Burma. London, pp.1-406.

Tikader, B.K. (1975). Some jumping spiders of the genus Zygoballus from India (family: Salticidae). Proceedings of the Indian Academy of Sciences 81(B): 150-153.
Tikader, B.K. and U.A. Gajbe (1976a). New spiders of Drassyllus from India (Gnaphosidae). Oriental Insects 10(3): 431434.

Tikader, B.K. and U.A. Gajbe (1976b). Studies on some spider of the genus Zelotes Gistel from India (Family: Gnaphosidae). Proceedings of the Indian Academy of Sciences 83B, No. 3: 109-122.

Tikader, B.K. (1980). Fauna of India, Spiders (Thomisidae), Vol. 1, Part 1.Zoological Survey of India, 1-247pp.

Tikader, B.K. and M.S. Malhotra (1980). Fauna of India, Spiders (Lycosidae) Vol. 1, Part 2. Zoological Survey of India, 248-447pp. Tikader, B.K. (1982a). Fauna of India, Spiders (Araneidae) Vol. 2, Part 1. Zoological Survey of India, 1-293pp.

Tikader, B.K. (1982b). Fauna of India, Spiders (Gnaphosidae) Vol. 2, Part 2. Zoological Survey of India, 295-536pp. 